o mitted from the table; if it had been inserted the 20 years and 2 months period would have counted as two 10 year periods.)

December 1860 to January 184I, interval ro years 2 months.

$$
\text { , I870 ", I881, , ro ," } 2 \text {," }
$$

Thus at least four periods (out of a possible seven) do not require much "screwing" to make them approximate to II-year epochs; while if we were to add in the long frost of 1850 we should have no less than six periods, showing a distinct recurrence.

It may not be quite clear why the remaining dates are inserted; but if they are analysed in the following manner thay are not uninstructive.

December 1813 to January 1838 , interval 22 years 2 months.

$$
\text { " I837 " I857, " } 19 \text { ", } 2 \text { ", }
$$

These periods, like the one 1840 to $186 \mathrm{I}$, tend to show that the intervals aproximate nearer to 22 years. How does F. M. S. obtain the intervals he quotes? As regards the last paragraph of the letter of F. M. S. respecting the "abnormal heat, cold, rain, \&c.," it is only necessary to say that he would have considerable difficulty to prove to Norman Lockyer, Meldrum, and others, that I I -year cycles do not exist, even if F. M. S. "screwed" his figures, as he seems to have done in his letter above.

H. W. C.

\section{Butterflies in Winter}

A countryman has shown me to-day two fine specimens of Vanessa urtica in a lively condition caught on the 4 th inst. in an empty room on the border of the New Forest, exposed to the severity of the late frost.

Southampton, February 8

FOHN GOULD, F.R.S.

$T$ HE grave has recently closed over the remains of a very remarkable man, and although the annals of science, we are proud to think, afford many instances of indomitable energy and unceasing perseverance rewarded, they have no greater record of success than is to be found in the life of John Gould. No one can regard the series of works written and illustrated by him without acknowledging that they are a monument of human energy, and the story of his life makes the fulfilment of these large enterprises the more interesting. In the character of the man we must look for the secret of his success, because it is well known that he possessed neither the advantages of wealth nor education at the commencement of his career, and yet he has left behind him a series of works the like of which will probably never be seen again; and this because it is rare to find the qualities of a naturalist, an artist, and a man of business combined in one and the same person. John Gould was all these in an eminent degree : he knew the characters of birds as well as any man living, and although it has often been said that he made too many species-and latterly it has been the fashion with certain writers to sink a good many of them---yet the monographer, travelling over the ground again, generally finds that the critic, and not Gould himself, was at fault. As an artist he possessed talent combined with the greatest taste, and this, added to the knowledge of botany, acquired in his early days, enabled him to give to the world the most beautiful series of pictures of animal life which have yet been produced. Certain special works, where tine pencils of Wolf or Keulemans have been employed, many vie with those of Gould, but taken in a collective sense, his splendid folios, full of coloured plates, are as yet without a rival. That he was a good man of business the fact that his writings were not only self-supporting, but further realised him a considerable fortune, is the best proof. Though in outward seeming he was stern and even somewhat brusque in manner, those who knew him well can vouch for the goodness of his heart, and can tell of many an act of kindness and charity, concealed from the world under a bluff exterior, and no one ever heard him speak unindly of any of his contemporaries. Straightforwardness was one of his especial characteristics, as well as an exact manner of doing business, paying for everything the moment the work was done; and this probably accounts for the way in which his artists, lithographers and colourers, worked for him for long periods of years.

Mr. Gould at his death was in his seventy-seventh year, having been born in September, I804. He was a native of Lyme in Dorsetshire, but when quite an infant his parents moved to the neighbourhood of Guildford When he was fourteen years of age his father was appointed a forcman in the Royal Gardens at Windsor, under Mr. J. T. Aiton, and here the lad had a grand opportunity of studying British birds in a state of nature; in his collection are still to be seen two magpies shot by himself and stuffed at the age of fourteen, which are even now most creditable specimens of taxidermy, and foreshadowed the excellence which be afterwards attained to in that art. Till the year 1827 , when he came to London, he was still employed in active gardening, having left Windsor for a post at Sir William Ingleby's at Ripley Castle in Yorkshire. Immediately after coming to town he was appointed curator to the Zoological Society's Museum, at that time in its infancy, and he enjoyed the intimate friendship of Mr. N. A. Vigors, then one of the leading English naturalists, and through him John Gould received his first opportunity of appearing as an author. So rare were Himalayan birds in those days that a small collection was thought worthy of description by Mr. Vigors in the Proceedings of the Zoological Society, and the figuring of these specimens was commenced by Mr. Gould under the title of "A Century of Birds from the Himalayan Mountains." By this time however an event had taken place which had an influence on the whole of his later life, viz., his marriage with Miss Coxen, the daughter of Mr. Nicholas Coxen of Kent. Besides her other accomplishments Mrs. Gould was an admirable draughtswoman, and, from her husband's sketches, she transferred to stone the figures of the above-named work. Its success was so great that in 1832 the "Bircls of Europe "was commenced, and finished in five large folio volumes in 1837 , while simultaneously, in 1834 , he issued a Monograph of the Rhamphastidæ or family of Toucans, and in 1838 a Monograph of the Trogonidæ or family of Trogons. To the last he maintained his love for these birds, and one of his most recently finished works was a second edition of the last-mentioned Monograph. It is a curious fact that when John Gould proposed to publish his first work, he applied to several of the leading firms in London, and not one of them would undertake to bring it out, so that it was only with reluctance that he began to issue the work on his own account. Besides these larger publications he had described the birds collected during the voyage of the Eeagle by his friend Mr. Darwin, and had contributed papers on other subjects to the Zoological Society's publications.

We now come to what we consider the most striking incident in Mr. Gould's life, one unsurpassed in its effects in the annals of ornithology. Beyond a few scattered descriptions by some of the older authors and an account of the Australian birds in the museum of the Linnean Society, by Messrs. Vigors and Horsfield, the birds of Australasia were very little known at the date we speak of. Accompanied therefore by his devoted wife, Mr. Gould proceeded in 1838 to study Australian birds in their own home, and he personally explored Tasmania, the islands in Bass's Straits, South Australia, and New South Wales, travelling 400 miles into the interior of the latter country. This voyage, specially undertaken for the purpose of obtaining an exact knowledge of Australian birds, must ever be reckoned as a distinct scientific achievement, and the accounts of the habits of some of the more remarkable species, such as the mound-building Megapodes and the Bower birds were quite triumphs in the way of field ornithology. Nests and eggs were collected as well as an excellent series of skins, both of mammals and birds, and here Mr. Gould's beautiful method of 
preparation was especially noticeable; some of his specimens, skinned more than thirty years ago, are as neat in appearance and as fresh as the day they were prepared. Returning in 1840, after two years' absence, he commenced the great work on the "Birds of Australia," which makes seven folio volumes and occupied seven years in its production, being completed in 1848 . One of the features of this work is the great increase in our knowledge of the range and habits of petrels and other seabirds, to which the author paid great attention during his travels.

Within a year of Mr. Gould's return from his adventurous voyage he had the misfortune to lose his wife, and for some time he was completely overwhelmed by his bereavement. His collectors in Australia too, about the same period, lost their lives; one of them, Mr. Gilbert, was killed during Dr. Leichhardt's expedition overland from Moreton Bay to Port Essington, and Mr. Drummond, while collecting in Western Australia, was also murdered by natives, and a third collector was killed by the explosion of a gun on one of the islands of Bass's Straits. It speaks volumes however for the zeal and energy with which Mr. Gould had prosecuted his researches in the Australian continent that very few birds, sufficient only to form a supplement in a single folio volume, have been discovered since he left the field of his labours in that quarter of the globe.

Another landmark in the career of this great ornithologist was the publication of his Monograph of the Trochilidæ, or Family of Humming Birds. These lovely little birds had been for a long time favourites with Mr. Gould, who gradually began to amass that fine collection which has been the admiration of naturalists for so many years. Taking advantage of the Great Exhibition of 1851 , he obtained permission from the Zoological Society to erect at his own cost a large building in their gardens in the Regent's Park, where the collection was open to the public at a charge of sixpence per head. A considerable sum was realised by this exhibition, and a large number of subscribers to his monograph was obtained, including nearly all the royal families of Europe. Though sketched by Mr. Gould himself (for even to the last days of his life he executed the designs for all his plates), the majority of the humming-birds were placed on stone by Mr. Richter, who also did the same for Mr. Gould's next work, "The Birds of Asia." We cannot but regard this as one of the most valuable of all the works done by the author, for, notwithstanding the fact that it is left unfinished at his death, it contains a large number of plates of species not eIsewhere figured. The "Mammals of Australia," produced simultaneously with the last-mentioned work, deserved, in Mr. Gould's own opinion, more credit for its issue than perhaps any work he had done, because it touched upon a branch of zoology of which he never pretended to have a very exact knowledge. So large however had been his collections of mammalia during his sojourn in Australia that some account of them seemed to be demanded, and he therefore published his large folio work; but the pecuniary results were less satisfactory than with any of his ornithological productions. His typical specimens of the Australian mammalia are in the national collection. No sooner were the humming-birds finished than his active brain conceived a new idea, to illustrate becomingly the birds of his native land, and he commenced the publication of the "Birds of Great Britain." Opinions may differ as to the merit of Mr. Gould's other works; volumes less ponderous than the folios which he adopted for the better figuring of the objects of the natural size, may take their place with the student; but no work of greater beauty will be produced than that on which John Gould, returning in his later life to his first love, bestowed the fulness of his energy and the acme of his artistic talent. The care bestowed on the plates of this work was remarkable, the aim of the author being to produce a picture of the birds as they appeared in their natural haunts, and especial pains were bestowed on the young, particularly those of the wading-birds and natatores. In this fine work most of the drawings were developed and placed on stone by Mr. W. Hart, who also executed all the plates of the later works.

In $1865 \mathrm{Mr}$. Gould republished his letterpress of the big work in an octavo form, under the title of "A Handbook to the Birds of Australia," but with all the additional species inserted in their proper families; these two volumes are therefore of great use to the student. After the completion of his work on "British Birds," Mr. Gould devoted himself to the continuation of the "Birds of Asia" and the Supplement to the "Birds of Australia," until in 1875 he commenced a work on the "Birds of New Guinea," which was to contain also descriptions of any new species to be discovered in Australia or any part of the Australian region. Of the last-named work eleven parts have appeared, and it was left unfinished at his death, as well as the following works :- a "Monograph of the Pittidæ or Ant-Thrushes of the Old World" (one part published), the Supplement to the "Monograph of the Hunming Birds" (two parts published), and the "Birds of Asia."

The above list enumerates, we believe, nearly all the works published by Mr. Gould with the exception of the "I cones Avium," issued about 1838, and containing supplementary plates to his previous volumes, with descriptions of new species, and the "Monograph of the Odontophorhinæ or Partridges of America." In addition to the folio volumes he was also in the habit of publishing the introductions to his larger works in an octavo form.

Many of the above details of Mr. Gould's life are taken from "Men of Eminence," aided by the personal recollections of the writer, who was for many years an intimate friend of the deceased, and knew him first as a successful trout-catcher on the Thames, for his prowess in throwing the fly was scarcely second to his skill as an artist. Were he to write an epitaph of John Gould he would do so in the words which Mr. Gould himself was fond of quoting:- "Here lies John Gould, the Bird-Man." The latter words were used by an old and intimate friend in introducing $\mathrm{Mr}$. Gould to another relative. We may hope that the Government, according to the well-known wishes of the deceased naturalist, will allow no false motives of economy to interfere with the purchase of $\mathrm{Mr}$. Gould's collection of birds for the British Museum, and that the disgraceful spectacle of his Australian collection (unrivalled to this day, and offered to the nation for the small sum of $1000 \%$.) being allowed to leave the country, may not be repeated.

\section{THE BLACKHEATH HOLES}

$T \mathrm{HE}$ chalk forming the base of the escarpment between Woolwich and the entrance to the valley of the Ravensbourne, dips at a low angle to the south-south-east under Greenwich Park and Blackheath, where it is overlaid by the Thanet Sands, estimated by Mr. Whitaker of the Geological Survey at 40 to 50 feet, the Reading and Woolwich Beds, consisting of shelly clays, sometimes 40 feet thick, associated near Lewisham with fine laminated sands. These beds are overlain by the Oldhaven or Blackheath gravels, reaching a thickness of about 50 feet, which have been largely dug for gravel in various parts of the district.

In the centre of this tract at Blackheath, on the west side of the angle of the roads from Greenwich Park to Blackheath Station, and from the Park to the Paragon, appeared in the early morning of Thursday, April 12, 1878, a subsidence near the row known as Rotten Row, referred to in these columns at the time, the hole being 8 or 9 yards in circumference. In November, 1880, appeared another hole near the gravel pit below Eliot Place 